\title{
Trends of tactical performance analysis in team sports: bridging the gap between research, training and competition
}

\author{
Júlio Garganta
}

https://doi.org/10.5628/rpcd.09.01.81
Centre of Research, Education, Innovation

and Intervention in Sport $\left(\mathrm{CIFI}^{2} \mathrm{D}\right)$

Faculty of Sports

University of Porto

Portugal

\section{ABSTRACT}

Performance in Team Sports is carried out through a long term and methodical training process planned to improve skills and competence required to deal with competitive demands. Despite that tactical constraint play a major role in Team Sports performance the history of its scientific analysis has been driven by physiological and biomechanical approach, paying little attention to the tactical behaviour of the players and team organisation. For coaches and researchers, tactical analyses can be helpful, since they offer the opportunity to identify match regularities and random features of game events. The information about performance is crucial to achieve individual and team efficacy, also because it constitutes a basic criterion for training process. Once tactical major features are identified, they can inform training and performance enhancement programs. Regardless the technological progress, the analysis of tactical performance in Team Sports remains an under-theorised field, since there was no significant amount of research undertaken to identify the most important factors underpinning performance. Thus, it seems relevant to find out concepts and methods allowing to assemble and to organise knowledge about game complexity and dynamic interaction properties of the teams. The main purpose of this paper is to point out that conceptual frame about tactical indicators in Team Sports should be a major orientation to bridge the gap between research, training and competition.

Key-words: team sports, tactics, performance analysis

\section{RESUMO}

Tendências da análise do desempenho táctico nos jogos desportivos: em busca da harmonia entre investigação, treino e competição

A performance nos jogos desportivos colectivos é viabilizada, em grande parte, pelo recurso a processos de treino metódicos e planeados a longo prazo para desenvolver habilidades e competências que permitam lidar de modo eficaz com as exigências das competições. Apesar de, reconhecidamente, os constrangimentos tácticos desempenharem um papel nuclear nos jogos desportivos colectivos, a investigação tem sido predominantemente orientada para as abordagens fisiológicas e biomecânicas, em detrimento da atenção devotada ao comportamento táctico dos jogadores e das equipas. A análise da performance táctica pode ser proficua para treinadores e investigadores, na medida em que possibilita a identificação de regularidades e contingências, com base na observação do modo como jogadores $e$ equipas engendram e gerem os eventos de jogo. Assim sendo, a informação sobre o desempenho táctico torna-se crucial para perseguir a eficácia individual e colectiva, também porque constitui um preceito fundamental para dar coerência ao processo de treino, na relação com a competição que o legitima. Uma vez identificadas as principais características e exigências tácticas, a partir delas é possivel tornar o treino mais específico e adequar outros programas de aprimoramento do desempenho.

Deste modo, o défice de investigação empreendida para identificar os constrangimentos mais relevantes que condicionam o rendimento nos jogos desportivos colectivos, nomeadamente no que se reporta ao desempenho táctico, justifica a necessidade de agenciar conceitos e métodos que permitam organizar o conhecimento sobre a complexidade do jogo e as propriedades de interacção dinâmica das equipas.

O propósito principal deste artigo é aduzir argumentos que mostrem que a procura e a identificação de indicadores tácticos relevantes em jogos desportivos colectivos constitui uma orientação fundamental para demandar a harmonia entre pesquisa, treino e competição neste grupo de modalidades.

Palavras-chave: jogos desportivos colectivos, táctica, análise da performance 


\section{INTRODUCTION}

The limits of human performance are continually being pushed in keeping with the Olympic motto output: 'stronger, higher, faster'(60). In effect, sports scientists, coaches, and athletes are continuously looking for ways to provide a slight, legal advantage in athletic performance (49).

Team Sports (TS) refer to games played between two opposing teams. The players interact directly and concurrently to achieve an objective that involves team members facilitating the movement of a ball or a similar item in accordance with a set of rules, in order to score points and to prevent the opposition from scoring $(14,38,62)$. In these sport disciplines, the performance is carried out through a long term and methodical training process planned to improve technical and tactical skills, as well as strategic competence, required to deal with match demands.

In TS, the activity of players and teams is developed by altering conditions, with the preponderance of tactical features depending on (14): 1) the sort of opposition amongst opponents and the kind of cooperation involving team-mates; 2 ) the huge degrees of freedom and variability; 3 ) the characteristics of technical skills to act in specific conditions.

Gréhaigne ${ }^{(22)}$ points out that TS brings in three main categories of problems, related with: a) space and time; b) information, and c) organization. Therefore, the French author highlights tactical and strategic facets of the game.

Taking into account the basic motion of players in its different modalities (standing, walking, jogging, moderate speed running, sprinting, ...), it is possible to state that the genuine reasons for its expression must be constantly based upon on a tactical/strategic purpose; the player stands or positions himself to some place, with higher or lower intensity, at a certain moment, in relation to the game configuration. Given that any action should have a tactical aim, the analysis of indicators such as the distance covered during the game, players' heart-rate, or time motion, can acquire a larger pertinence when related to the game tactical requests, namely the style of play, the offensive and defensive play methods, and the positional and functional status of the players $(14,15)$. Thus, in TS setting, the Olympic slogan looks incomplete - "stronger, higher, faster" - because it lacks the word "smarter". Smartness in TS refers to the capacity to deal with space, time and task constraints, not only to react to the different game scenarios but also acting in order to create them.

Despite tactical constraints plays a main role in TS, only a few papers deal explicitly with scientific approach on tactical setting. In fact, the history of scientific analysis in TS has been driven by physiological and biomechanical approach, paying little attention to the tactical behaviour of the players and team organization.

The focal purpose of this paper is to argue that research about tactical features, mainly in what concerns team's organization, in different game phases (offensive, defensive and transition play), should be a major orientation to bridge the gap between research, training and competition in TS.

\section{TACTICAL MODELLING: CONCEPTS AND IDEAS}

For coaches and researchers, tactical modelling can be helpful because it offers the opportunity to identify match regularities and random features of game events according to the offensive and defensive play. Obviously the information about performance is crucial to achieve individual and team efficacy, also because it constitutes a basic criterion for the training process.

Several authors have been trying to outline significant tactical performance features in $\operatorname{TS}(7,9,14,20,21$, $29,38,41,48,51,56)$. In this range, game modelling has been used to provide detection of patterns among match play events, according to the characteristics that afford players and team's success or failure. As stated by Lames \& Hansen (37), it is important to ask whether models contain the essential attributes of the original game sport observed. That's why, recently, game sports research has become aware that another aspect of the model building process has perhaps not been enough attention: the purpose of the model.

In order to achiever deeper insight into the TS tactical game, it is necessary to record the substantial tactical actions in a chronological, sequential order, so the stream of tactical behaviour can be recognized(55). In view of TS as the composite of complex interactions, systemic approach brings us to consider, among others, two main organizational levels: 
"match" and "team"(25). A match ${ }^{1}$ constitutes a complex system and the central notion of opposition leads us to consider two teams as interacting organized systems ${ }^{(24)}$.

The game may be thought of as living in the regions of meta-stability (see Kelso(34), where individual actions may serve to destabilize or (re)stabilize the system. The facility with which an attacker or a defender may destabilize or (re)stabilize the system would be considered a hallmark of quality in sport competition. In general terms, the ability of a team to destabilize or (re)stabilize a system might be examined at critical junctures of a game, say on the occurrence of an unexpected change of ball possession. Modelling a dynamic system means mapping not only its components and input-output behaviour but also in particular its components interaction ${ }^{(4,14,24,}$ 41, 53). From this viewpoint, the information about the interaction processes generated by the interactivity by teammates and opponents happens to show an outstanding relevancy because observing how interaction in a concurrent and competitive situation occurs can facilitate the design of specific and advantageous preparation.

To date research does not progress significantly further than the original work of McGarry \& Franks(43) and Hughes et al.(31) to develop new and inclusive methods of dynamic analysis of sports contests, and particularly in TS. Nevertheless, dynamic systems analyses may hold the key to unlocking the "hidden logic" of sports performance and variability within ${ }^{(19)}$. The potential of these models to concentrate enormously complex behaviour into simple expressions has been confirmed $(4,30,31,38,53,55)$ and offers a significant advantage over the labour intensive and inefficient approach required within traditional notational analysis.

In order to describe and interpret game sequences in different sports, Anguera et al.(2) suggest a noteworthy tool - the Observational Methodology. In this scope some authors have been using sequential analysis and polar-coordinates technique in their works $(1,5,11,12,40,52,56,59)$.

Garganta(14) put forward an approach to game observation based on a double level analysis plan: i) the creation of a theoretical map with relevant match performance indicators regarding tactical organiza- tion; ii) the observation of game sequences and exploitation of data coming from both qualitative and quantitative analysis of team's and player's organization.

Such an intention is very challenging due the nature and diversity of the constraints that compete for the success in TS, namely: i) the complexity concerning the plentiful relationships among the players $(24,64)$ : ii) the fact that game events do not correspond to a predictable sequence of actions ${ }^{(8,13)}$; iii) the acute sensitivity of team and player's behaviours to the initial conditions, taking into account the large amount of variables and its interaction ${ }^{(14,39)}$. For instance, in sports disciplines such as Soccer, Basketball or Handball, the teams compete for possession of the ball, which must be passed through a goal, while in Volleyball, the teams pass the ball in an attempt to place it in contact with an area of the opponents playing field.

The teams involved in a match behave similar to self-organized systems searching for order and shape in a macroscopic plan, according to the interactions produced by the players ${ }^{(18)}$. The individuality and degrees of freedom of team's performance are dependent on a number of players and their possible interactions in game ${ }^{(39)}$. Each team aims to disturb or to break the opponents' balance, with the intention to generate disorder in its organization. On the other hand, teams intend to assure their own stability and organization. This way, the actions performed along the matches tend to assure space and time advantage over the contender, which means that the confrontation determines, usually, a winner and a loser.

Because teams represent dynamical systems ${ }^{2}$ organised in accordance with principles and prescriptions, players and team's behaviour is generated from the tension among regularities $(14,44,57)$ and the production of novelty $(14,21)$. In this sense, teams proceed as specialised systems strongly dominated by strategy and heuristic competences ${ }^{(18)}$.

Some years ago Leon Teodorescu(61) claims that it is not advisable to reduce TS to any algorithm model, because team action does not represent predictable sequences. Gréhaigne ${ }^{(23)}$ appeals for a type of heuristic reasoning and he reinforces this idea referring that if the cascade of decisions will be restricted to 
an algorithm of binary choice, an impoverishment necessarily takes place, bringing about a limitation in game analysis. Lames \& Hansen(37) alleged that the multi-causal structure of diagnosis in TS demands an interpretative rather than algorithmic approach.

The swot up of team's and player's tactical organization afford the possibility to identify game events, namely the identification of some pattern expressing preferential ways or forms of action, and the distinctive characters showing the variability of behaviours and events $(14,17)$.

Lames \& McGarry (38) asserts that what we see by observing a sports game is a dynamical interaction process in which measures and countermeasures are taken in an attempt to overcome the opponent. This implies that the behaviour produced is not primarily the expression of stable properties of the individual players. In this context, the decision-making behaviour is best considered at the level of the performerenvironment relationship and viewed as emerging from the interactions of individuals with environmental constraints over time specific functional goals(3).

Therefore, the difficulty is that an adequate interpretation of numerical and visual data has to consider individual circumstances (tactics, strategy), but also situational aspects like physical and cognitive processes during the game, the quality of opponent and the preparation level(37).

\section{The key role of tactical performance indicators}

The last few years have seen considerable research on the performance analysis of sport competition (for a review see 28). The introduction of computer technology facilitated the detailed recording and analysis of sports behaviours and took centre stage in the early development of various notation systems. The assumption implicit in many of these initial studies was that the recorded variables were relevant to the performance outcome. On this expectation, the coach would seek out the critical performance features to change future behaviours on the basis of information gathered from past performances ${ }^{(41)}$. Although we do not deny the importance of videotechnology, mathematical methods or software and hardware improvement, the actual strategy must focus on effort to assemble indicators that would be able to describe main game events, considering the opposition and cooperation relationships among the players and teams. Much more than figures, information elapses from the notation and interpretation of the amount of tactical modelling of game play. This implies to understand the game beyond the analysis and notation systems. Match analysts must be able to check the relevance and descriptive power of performance indicators and to distinguish the core features of the game.

According to Hughes \& Bartlett( ${ }^{(33)}$, a performance indicator is a selection, or combination, of action variables that aims to define some or all aspects of a performance. Clearly, to be useful, performance indicators should relate to successful performance or outcome. Analysts and coaches use performance indicators to assess the performance of an individual, a team or elements of a team.

Also Hughes \& Bartlett( ${ }^{(33)}$ affirm that the selection and use of performance indicators depend upon the research questions being posed. Teams and players are either 'actors' or 'reactors'. Actors are more likely to initiate a perturbation and to destabilize the balance, whereas reactors are more likely to respond to a perturbation and to restore the balance to some semblance of stability. In such the team that lead phase relation (action) can take advantage over the team with the lag phase relation (reaction), which should materialize in a winning outcome.

The notion that a perturbation may lead to a disruption in sports behaviour has been analysed in soccer (see 24, for a related consideration of the changing configurations).

Hughes et al.(31) defined a perturbation in soccer as an incident that changes the rhythmic flow of attacking and defending, leading to a shooting opportunity. For example, a perturbation could be identified from a penetrating pass, a dribble, a change of pace or any skill that creates a disruption in the defence and allows an attacker a shooting opportunity. In some cases, a perturbation of the defence may not result in a shot, owing to defensive skills or a lack of skill in attack. This reasoning supposes that the defending team looks to (re)stabilize the just destabilized system, in effect dampening or 'smoothing out' the disruption caused by the perturbation. If a perturbation should result in a shooting opportunity, then 
this event is termed a 'critical incident'. Using this definition, Hughes et al.(31) reported significant differences in the goal to perturbation ratios between successful and unsuccessful teams in the 1996 European Championships. Such an analysis supposed that a critical incident (a shot on goal) must be preceded by a perturbation - that is, some aspect of skill that disrupted the normal rhythm of the game.

The collective behaviour of a complex system cannot be explained from separate investigations of the behaviour of its parts ${ }^{(45)}$. Instead, the system must be viewed in its entirety and then reduced to a minimum but universal set of principles, rather than to the elemental properties(35).

It was recognised that some characteristics of dynamic systems - namely transient periods of instability - were occurring naturally within observed sports performance. McGarry et al.(41), therefore reasoned, and later confirmed(46) that a stability disrupting perturbation occurred when the usual stable rhythm of play was disturbed by extreme elements of high or low skill. It became clear that the analysis of perturbations in sport offered a more critical and dynamic method of investigation on "dynamical configuration of play"(24) and therefore a significant step towards effective support to coaches and performance.

\section{WHERE TO LOOK TO "SEE" TACTICAL RELEVANT INDICATORS?}

A team game is a global event made up of several related micro-events. Individual members must harmonise into an effective unit in order to achieve the desired result. In such contexts the assessment of how well the team is playing and how much individuals contribute to team effort presents a challenge both to the coach and to sport scientists(6).

Perl \& Weber(54) held that the processes in sport can be described as time series of patterns, which can as well characterize situations (e.g. positions on the playground) as activities (e.g., moving of players). Tools such neural networks permit recognition and classification of these patterns.

In TS setting, Schöllhorn(58) illustrates some holistic team qualities for describing the behaviour of a team in space and time as a whole, namely the time cours- es of movements on the field, the area covered by players, the team's geometric shape in time, and the movement of team geometric centre.

During the last years, some studies have attempted to provide a theoretical basis to performance analysis research in terms of feature identification $(10,14,51)$ and essential variables which characterise game pat-

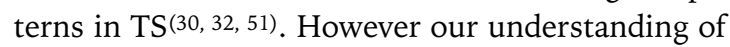
critical behaviours still remains in its infancy.

In a large part of several works, the authors gather and characterise amounts of data and describe the game variables behaviour, restricting their analysis to the situations leading to score. Nevertheless, the description of the offensive process and the evaluation of its effectiveness based only on the score opportunities, only allow a very restricted understanding of the game dynamics and team performance $^{(15,27) \text {. }}$

For researchers and coaches, it seems relevant to focus not only on the scoring actions, but also on other ones that permit to notice teams' production, in conformity with the cascade of purposes concerning the attack, defence and turnovers. In this way, the holistic analyses that point out team organisation, through the identification of regularities and random features of game actions, considering offensive and defensive efficacy, could be advantageous. It justifies searching for vital indicators concerning game events and so its required to scrutinize the transitions and metamorphosis that show the dynamical flow of player's and team's performance. For example, Lago \& Martin(36) made an empirical research about the determinants of ball possession as a performance indicator in soccer; and Garganta(14) suggests that tactical performance indicators should reproduce the relative importance of illustrative latent variables, e.g., time, space and game playing tasks (Figure 1), as well as how players and teams exploit these aspects of performance. These will be reflected in the ways that individuals and teams attack and defend, how they use the spaces in the playing surface and the variety of playing actions $(14,17,42)$.

As such, the main subject of tactical analysis should not be the player's actions, taken disjointedly, but the game play sequences resulting from the actions that occur during the different phases of the match. 


\begin{tabular}{|c|c|c|c|c|c|}
\hline \multirow{5}{*}{$\begin{array}{r}\text { Figure 1. Example of latent varia- } \\
\text { bles and tactical } \\
\text { performance indicators in Soccer } \\
\text { [Adap. Garganta(15)]. }\end{array}$} & $\begin{array}{l}\text { Latent } \\
\text { variables }\end{array}$ & $\begin{array}{l}\text { SPACE } \\
\text { Place of action }\end{array}$ & $\begin{array}{l}\text { TIME } \\
\text { Action time }\end{array}$ & $\begin{array}{l}\text { GAME TASK } \\
\text { Type of action }\end{array}$ & 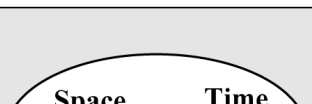 \\
\hline & $\begin{array}{l}\text { Tactical } \\
\text { Performance } \\
\text { Indicators }\end{array}$ & $\begin{array}{l}\text { Effective play- } \\
\text { space }\end{array}$ & $\begin{array}{l}\text { Frequency of } \\
\text { events }\end{array}$ & Interceptions & $\begin{array}{l}\text { Offensive and defensive } \\
\text { styles and methods of } \\
\text { playing }\end{array}$ \\
\hline & & $\begin{array}{l}\text { Paths of } \\
\text { players } \\
\text { movement }\end{array}$ & $\begin{array}{l}\text { Individual } \\
\text { and team } \\
\text { pace }\end{array}$ & Turnovers & Type of game sequences \\
\hline & & $\begin{array}{l}\text { Paths of ball } \\
\text { circulation }\end{array}$ & $\begin{array}{l}\text { Time of ball } \\
\text { possession }\end{array}$ & Passes & $\begin{array}{l}\text { Opposition and } \\
\text { cooperation setting }\end{array}$ \\
\hline & & $\begin{array}{l}\text { Players' action } \\
\text { zone }\end{array}$ & & Shots in target & $\begin{array}{l}\text { Set plays efficacy: offensive } \\
\text { and defensive }\end{array}$ \\
\hline
\end{tabular}

Behaviours are significant if they brake the balance attack/defence of the opponent, or because they exhibit a certain permanence in the variability of actions.

From this point of view, such a change implies the construction of observational and notational systems taking into account (Figure 2): the match organisation, starting from the features of sequential actions (tactical units), performed by the teams; the characteristics of the sequences leading to different outcomes; and the situations in which, whether a score occurs or not, there is a perturbation in the balance attack/defence.

While the vital challenge to players in TS is to generate and to manage interaction in order to organize the own team and to brake the opponent's balance, tactical features must be understood as game "functional units", containing the crucial information about match play organization and its efficacy. Hence, it is possible to use information about the organization patterns revealed by a team along several games to come up to conclusions about the effectiveness of players' behaviour in other games. Starting from an analysis of this type it seems perti- nent to design models that formalise team's organization according to variations and regularities that configure match play events, according to the game phases, i.e., attack, defence and transition play.

\section{FINAL REMARKS}

Regardless the technological progress, tactical modelling remains an under-theorised field, since there was no significant amount of research undertaken to identify tactical features underpinning performance in TS. Thus, it seems relevant to find out concepts and methods allowing to assemble and to organise knowledge about game complexity and dynamic interaction properties of the teams. Once tactical focal features and its pertinence are identified, they can inform training and performance enhancement programmes. So, it has to be realised relevant coupling of information from game observation and the player's and team's training process ${ }^{(37)}$.

The question is, as states Perl(53), how tactical modelling can help to analyse and understand the present state as well as predict the future behaviour of a dynamic system, in order to update training and competition. Because of their complex internal inter- 


\begin{tabular}{|lcc|}
\hline \multicolumn{3}{|c|}{ Match analysis } \\
Player & $\leadsto$ & Team \\
Output & $\leadsto$ & Organization \\
$\begin{array}{l}\text { Remote } \\
\text { data }\end{array}$ & $\leadsto$ & $\begin{array}{c}\text { Sequence } \\
\text { Analysis }\end{array}$ \\
$\begin{array}{l}\text { Individual } \\
\text { skills }\end{array}$ & $\leadsto$ & $\begin{array}{c}\text { Tactical } \\
\text { features }\end{array}$ \\
\hline
\end{tabular}

actions, the time-dependent behaviour of dynamic systems cannot be predicted using static description models only. Instead, models have to be developed that reflect the system dynamics and help to simulate its behaviour.

Memmert \& Perl(47) refers that to evaluate performance data from TS, normally qualitative and quantitative methods are used separately, and suggested the combination of net-based qualitative analyses and stochastic quantitative analyses to improve the information output significantly.

Neville, Atkinson \& Hughes ${ }^{(49)}$ note that despite many sort of research methods and techniques to model performance in sport (i.e., empirical modelling, stochastic modelling, dynamic systems, neural networks, and fuzzy logic), used singly or in combination, to date, results have been disappointing practically.

In fact, during the last years the use of computers and sophisticated software develops clearly faster than the improvement of concepts and ideas about how to observe and to learn from starting tactical game setting and its dynamical properties.

However, and being essential to decide what information is important and whether it can be used to improve performance ${ }^{(6)}$, the decisions regarding strategies for collecting data, processing information and presenting the results are connected with the way of thinking(4).

For that reason, methods and tools to modelling performance in TS need not to be exclusive of each other. A hybrid type of description (or model) may be appropriate in the future. Thus, further research on sports contests using various types of system descriptions is warranted ${ }^{49}$.
We do not dare to doubt the importance concerning technological development in analysis of performance in TS. Nevertheless, we support that the technological sophistication is not sufficient to observe and to note efficiently game features neither to understand its configurations. Performance analysis becomes useful whenever it corresponds to the progressive refinement and extension of the observational variables, in the sense of increasing its descriptive and explanatory potential according to the representative game events.

Consequently, the dynamic interactions expressed by the balance and misbalance of team organization, seems to be key-features to describe and shape performance in TS. Considering the complexity and uncertainty of TS $(14,63)$, deterministic modelling seems not appropriate to set up performance analysis. As states Balagué \& Torrents ${ }^{4}$ and Lames \& McGarry(37), behind the use of mathematical modelling, simulation techniques or computing techniques, it is imperative to include qualitative research methods to arrive at the necessary inference for sport practice.

Searching for identification and interpretation of substantial game behaviour, it's imperative to assemble information based on quantities of quality of game playing. In this sense we must be aware of "game flow" and its changes ${ }^{(16)}$, developing concepts and tools from the dynamic systems approach and computer science to cope with complexity(4).

First we must found (the accurate variables and indicators); then we have to search for its expression in the match. In another words, the game can answer to all our questions ... if we know how and what to ask.

As it seems pertinent to create and to improve dynamics-sensitive tools to understand game's logic in TS, according tactical stream (see Gréhaigne, Mahut \& Fernandez ${ }^{(26)}$, game analysts and match observers should be team sport specialists prior to technological experts. May be this is one of the keys to bridge the gap towards a comprehensive link between research, training and competition.

\section{ACKNOWLEDGEMENTS}

The author wishes to thank Marc Verlinden (Vrije Universiteit Brussel) for his help, suggestions and feedback. 


\section{NOTAS}

${ }^{1}$ According to Lebed (39), "game" is as system of ordered information, a code of rules restricting and defining participants" behaviours in specially constructed conditions of space, time and means; "match" is a process of participating sides (systems) competing between them; "game playing" is a system, which directly functions in sport competition conditions. A single player or a team of players can represent such a system. 2 According to McGarry \& Franks $(45)$, a dynamical system is a type of complex system, one in which regularity self-organizes from within as a result of information exchanges that occur both inside and outside the system (i.e., among the parts that comprise the system, and between the system and its surrounding constraints, respectively).

\section{REFERENCES}

1. Amaral R, Garganta J (2005). A modelação do jogo em Futsal. Análise sequencial do $1 \times 1$ no processo ofensivo. Revista Portuguesa de Ciências do Desporto, 3 (5): 298-310.

2. Anguera M, Blanco A, Losada J, Hernández A (2000). La metodología observacional en el deporte: Conceptos básicos. Lecturas: EF y Deportes. Revista Digital 5 (24).

3. Araújo D, Davids K, Hristovski R (2006). The ecological dynamics of decision making in sport. Psychology of Sport and Exercise 7 (6): 653-676.

4. Balagué N, Torrents C (2005). Thinking before computing: changing approaches in sports performance. International Journal of Computer Science in Sport 4 (1): 5-13.

5. Caldeira N (2001). Estudo da relevância contextual das situações de 1x1, no processo ofensivo em Futebol com recurso à Análise Sequencial. Dissertação de Mestrado em Treino de Alto Rendimento. Faculdade de Ciências do Desporto e de Educação Física da Universidade do Porto.

6. Carling C, Williams M, Reilly T (2005). Handbook of Soccer Match Analysis. A systematic approach to improving performance. London: Routledge.

7. Deleplace R (1979). Rugby de mouvement - Rugby total. Paris: E.P.S.

8. Dufour W (1993). Computer-assisted scouting in soccer. In Science and Football II: Proceedings of the Second World Congress of Science and Football (pp. 160-166). Eindhoven, Netherlands.

9. Dugrand M (1989). Football de la transparence à la complexité. Paris: Universitaires de France.

10. Ferreira A, Volossovitch A, Gonçalves I (2003). Methodological and dynamic perspective to determine critical moments on sport game. International Journal of Computer Science in Sport 2(2): 119-122.

11. Ferreira D (2006). Métodos de jogo ofensivo na transição defesa-ataque em Andebol. Estudo do contra-ataque e do ataque rápido com recurso à análise sequencial. Porto: Davide Ferreira. Dissertação de Mestrado em Treino de Alto Rendimento. Faculdade de Ciências do Desporto e de Educação Física da Universidade do Porto.

12. Ferreira N (2006). O processo ofensivo em desigualdade numéri- ca no Andebol. Um estudo com recurso à análise sequencial. Dissertação de Mestrado em Treino de Alto Rendimento. Faculdade de Ciências do Desporto e de Educação Física da Universidade do Porto.

13. Garganta J (1994). Para uma teoria dos jogos desportivos colectivos. In A. Graça \& J. Oliveira (Eds.), O ensino dos jogos desportivos ( $1^{\mathrm{a}}$ ed., Vol. 1, pp. 11-26). Faculdade de Desporto da Universidade do Porto: Rainho \& Neves Lda.

14. Garganta J (1997). Modelação táctica do jogo de futebol - estudo da organização da fase ofensiva em equipas de alto rendimento. Dissertação de Doutoramento. Faculdade de Ciências do Desporto e de Educação Física da Universidade do Porto.

15. Garganta J (2001). Tactical modelling in Soccer: a critical view. In M. Hughes \& F. Tavares (Eds.), Proceedings of $I V$ World Congress of Notational Analysis of Sport (pp. 33-40). Faculdade de Desporto da Universidade do Porto.

16. Garganta J (2005). Dos constrangimentos da acção à liberdade de (inter)acção, para um futebol com pés... e cabeça. In A. Duarte (Ed.), O contexto da decisão - a acção táctica do desporto (Vol. 1, pp. 179-190). Lisboa: Visão e Contextos Lda.

17. Garganta J (2007). Modelação táctica em jogos desportivos: a desejável cumplicidade entre pesquisa, treino e competição. In F. Tavares, A. Graça \& J. Garganta (Eds.), Proceedings do $1^{\circ}$ Congresso Internacional de Jogos Desportivos - Cd-Rom. Porto: Faculdade de Desporto da Universidade do Porto e Centro de Estudos dos Jogos Deportivos.

18. Garganta J, Cunha e Silva P (2000). O jogo de futebol: entre o caos e a regra. Horizonte Revista de Educação Física e Desporto 16(91): 5-8.

19. Garganta J, Gréhaigne JF (1999). Abordagem sistémica do jogo de futebol: moda ou necessidade. Revista Movimento 5(10): 40-50.

20. Godik M, Popov A (1993). Estructura de la actividad de juego (competitiva) de los jugadores como base para la organización del proceso de entrenamiento. In M. Godik \& A. Popov (Eds.), La preparación del futbolista (pp. 35-67). Barcelona: Paidotribo.

21. Gréhaigne JF (1989). "Football de Mouvement". Vers une approche systémique du jeu. UFR-STAPS: Jean Gréhaigne. Dissertation de Doctorat, Université de Bourgogne.

22. Gréhaigne JF (1991). A new method of goal analysis. Science and Football 5: 10-16.

23. Gréhaigne JF (1992). L'organisation du jeu en football. Paris: Joinville-le-Pont.

24. Gréhaigne JF, Bouthier D, David B (1997). Dynamic-system analysis of opponent relationships in collective actions in soccer. Journal of Sports Sciences 15: 137-149.

25. Gréhaigne JF., \& Godbout, P. (1995). Tactical Knowledge in Team Sports from a Constructivist and Cognitivist Perspective. Quest 47(4): 490-505.

26. Gréhaigne, JF, Mahut B, Fernandez A (2001). Qualitative observation tools to analyze soccer. International Journal of Performance Analysis in Sport 1(1): 52-61.

27. Harris S, Reilly T (1988). Space, teamwork and attacking success in soccer. In T. Reilly, A. Lees, K. Davis \& W. Murphy (Eds.), Science and Football - Proceedings on the First World Congress of Science and Football (pp. 322-328). Liverpool, 1987. London-New York: E. \& F.N. Spon.

28. Hughes C, Franks I (1997). Notational analysis of sport. London: E. \& F.N Spon. 
29. Hughes M (1996). Notational Analysis. In T. Reilly (Ed.), Science and soccer (pp. 343-361). London: E. \& F.N. Spon.

30. Hughes M, David R, Dawkin N (2001). Critical Incidents leading to shooting in soccer. In M. Hughes (Ed.), Notational Analysis of Sport III (pp. 10-21). Cardiff: UWIC Press.

31. Hughes M, Dawkins N, David D, Mills J (1998). The perturbation effect and goal opportunities in soccer. Journal of Sports Sciences 16: 20-21.

32. Hughes M, Reed D (2005). Creating a performance profile using perturbations in soccer. In D. Milanovic \& F. Prot. (Eds.), Proceedings of 4th International Scientific Conference on Kinesiology (pp. 34-53). Zagreb: University of Zagreb, Croatia.

33. Hughes MD, Bartlett RM (2002). The use of performance indicators in performance analysis. Journal of Sports Sciences 20(10): 739-754.

34. Kelso S (1995). Dynamic Patterns: The self-organization of brain and behavior. Champaign, Illinois: Human Kinetics.

35. Kelso S, Tuller B (1984). A dynamical base for action systems. In M. Gazzaniga (Ed.), Handbook of cognitive neuroscience (pp. 321-356). New York: Plenum Press.

36. Lago C, Martin R (2007). Determinants of possession of the ball in soccer. Journal of Sports Sciences 25(9): 969-974.

37. Lames M, Hansen G (2001). Designing observational systems to support top-level teams in game sports. International Journal of Performance Analysis in Sport 1(1): 8390.

38. Lames M, McGarry T (2007). On the search for reliable performance indicators in game sports. International Journal of Performance Analysis in Sport 7(1): 62-79.

39. Lebed F (2006). System approach to games and competitive playing. European Journal of Sport Science 6(1).

40. Lopes JAF (2007). Análise diacrónica heterocontingente dos métodos de jogo ofensivo no futebol: estudo em equipas de nível competitivo superior. Dissertação de Mestrado em Treino de Alto Rendimento. Faculdade de Desporto da Universidade do Porto.

41. McGarry T, Anderson D, Wallace S, Hughes M, Franks I (2002). Sport competition as a dynamical self-organizing system. Journal of Sports Sciences 20(10): 771-781.

42. McGarry T, Franks IM (1994). A stochastic approach to predicting competition squash match-play. Journal of Sports Sciences 12: 573-584.

43. McGarry T, Franks IM (1995). Modeling competitive squash performance from quantitative analysis. Human Performance 8(2): 113-129.

44. McGarry T, Franks IM (1996). In search of invariant athletic behaviour in sport: an example from championship squash match-play. Journal of Sports Sciences 14(5): 445-456.

45. McGarry T, Franks IM (2007). System approach to games and competitive playing: Reply to Lebed (2006). European Journal of Sport Science 7(1): 47-53.

46. McGarry T, Khan MA, Franks IM (1999). On the presence and absence of behavior traits in sports: an example from championship squash match-play. Journal of Sports Sciences 17: 297-311.

47. Memmert D, Perl J (2006). Game intelligence analysis by means of a combination of variance-analysis and neural networks. International Journal of Computer Science in Sport 4(1): 29-39.

48. Moutinho C (2000). Estudo da estrutura interna das acções da distribuição em equipas de voleibol de alto nível de rendimento contributo para a caracterização e prospectiva do jogador distribuidor. Dissertação de Doutoramento. Faculdade de Ciências do Desporto e de Educação Física da Universidade do Porto.

49. Neville A, Atkinson G, Hughes M (2008). Twenty-five years of sport performance research in the Journal of Sport Sciences. Journal of Sport Sciences 26(4): 413-426.

50. Palut Y, Zanone PG (2003). Tennis investigation as a nonlinear complex system. International Journal of Computer Science in Sport 2(2): 132-134.

51. Palut Y, Zanone PG (2005). A dynamical analysis of tennis: Concepts and data. Journal of Sports Sciences 23(10):10211032.

52. Pereira N (2006). Análise diacrónica da transição defesa-ataque em equipas de Futebol de rendimento superior. Estudo dos padrões de jogo recorrendo à Análise Sequencial e de Coordenadas Polares. Dissertação de Mestrado em Treino de Alto Rendimento. Faculdade de Ciências do Desporto e de Educação Física da Universidade do Porto.

53. Perl J (2004). Modelling dynamic systems basic aspects and application to performance analysis. International Journal of Computer Science in Sport 3(2):19-28.

54. Perl J, Weber K (2004). A neural network approach to pattern learning in sport. International Journal of Computer Science in Sport 3(1): 67-70.

55. Pfeiffer M, Perl J (2006). Analysis of tactical structures in team handball by means of artificial neural networks. International Journal of Computer Science in Sport 5(1): 4-14.

56. Prudente J (2004). Análise da performance táctico-técnica no Andebol de alto nível: estudo das acções ofensivas com recurso à análise sequencial. Dissertação de Doutoramento. Universidade da Madeira.

57. Reep C, Benjamin B (1968). Skill and chance in Association Football. Journal Royal Soc. Statistic 1(131):581585.

58. Schöllhorn W (2003). Coordination dynamics and its consequences on sports. International Journal of Computer Science in Sport 2(2):40-46.

59. Silva AP (2004). Modelação de padrões de jogo em Futebol de alto rendimento. Um estudo realizado no Mundial 2002 Coreia/Japão, com recurso à análise sequencial e à técnica de coordenadas polares. Madri: A. Silva. Dissertação de Mestrado em Treino de Alto Rendimento. Universidade Autónoma de Madrid.

60. Smith DJ (2003). A framework for understanding the training process leading to elite performance. Sports Medicine 33(15):1103-1126.

61. Teodorescu L (1985). Contributi al concetto di gioco sportivo di squadra. / Contribution to the concept of team sport. In In, L'insegnamento dei giochi sportivi, Rome, CONI, Scuola dello Sport, 1985, p. 19-35. Italy.

62. Thomas A (2006). The impact of puck possession and location on Ice Hockey strategy. Journal of Quantitative Analysis in Sports 2(1):1-16.

63. Wiemeyer J (2003). Who should play in which position in soccer? Empirical evidence and unconventional modelling International Journal of Performance Analysis in Sport 3(1):118.

64. Worthington E (1974). Learning \& teaching soccer skills. California: Hal Leighton Printing Company. 